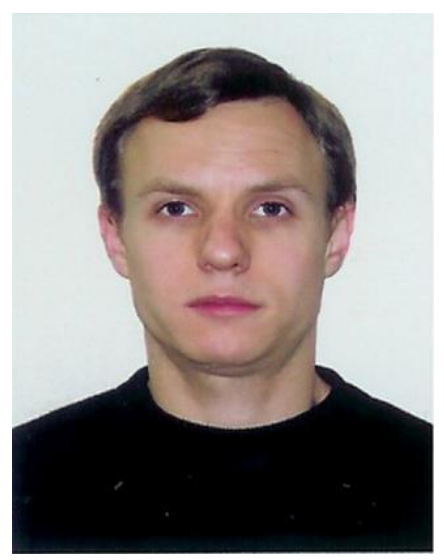

\author{
Володимир Шевченко, \\ докторант Інституту спеціальної педагогіки \\ НАПН України, \\ (м. Київ, Україна)
}

\author{
Volodymyr Shevchenko, \\ doctoral student of the Institute of Special Pedagogics \\ of the National Academy of Sciences of Ukraine, \\ (Kyiv, Ukraine) \\ shevchenko_volodumur@ukr.net \\ ORCID ID 0000-0003-0119-3206
}

удк [37:376]-043.86(4:477)-042.2

\title{
ВКЛЮЧЕННЯ ДІТЕЙ 3 ОСОБЛИВИМИ ПОТРЕБАМИ В СОЦІАЛЬНО-ОСВІТНЄ СЕРЕДОВИЩЕ
}

Анотація. У статті автор розглядає важливе питання для сучасної освіти в Україні, яка перебуває в стадії реформування, - включення дітей з особливими потребами в соціально-освітнє середовище. Він ставить за мету визначити можливості для включення дітей з особливими потребами до соціально-освітнього середовища і розкрити проблеми адаптації за допомогою методів аналізу, синтезу, систематизації та узагальнення. Автор визначає поняття «соціалізація», «соціальне середовище» і «соціально-освітнє середовище». Він наголошує на особливостях взаємодії дітей з особливими потребами із соціальним середовищем. Автор зазначає, що інтеграція та соціалізація дітей з особливими потребами - це складний і тривалий процес. Він вимагає суттєвих змін у ставленні до дітей

з інвалідністю, які потребують не лише педагогічної та психологічної підтримки і заходів реабілітації, а й належних умов для актуалізації своїх здібностей, розвитку особистих якостей та потреб у соціальному, моральному і духовному самовдосконаленні. Включення дітей з особливими потребами в соціальне середовище полягає у створенні психологічнопедагогічних умов для навчання та спілкування, взаємодії такої дитини в освітньому закладі. Автор статті також зазначає, що повноцінне виховання дітей з особливими потребами не може відбуватися окремо від сім'ї. Тому сім'я $є$ досить важливим і значущим компонентом для соціалізації дітей з особливими потребами. Саме їй належить найголовніша та найвідповідальніша роль у цьому процесі, фахівці ж мають допомагати та підтримувати такі родини. Автором встановлено, що на сьогодні вплив батьків дітей з особливими потребами на систему надання освітньо-реабілітаційних послуг та на прийняття державних рішень у цій сфері $€$ досить значним. Необхідно розкрити потенціал їхніх можливостей для максимальної інтеграції дітей у соціально-освітнє середовище.

Ключові слова: інклюзивна освіта, діти з особливими потребам, соціалізація, соціальне середовище, соціально-освітнє середовище, сім'я, компетентність.

\section{INCLUSION OF CHILDREN WITH SPECIAL NEEDS IN THE SOCIAL AND EDUCATIONAL ENVIRONMENT}

\begin{abstract}
In the article the author considers an important issue for modern education in Ukraine, which is in the process of reforming. Inclusion of children with special needs aims to identify opportunities for them in the social and educational environment. Also, to discover problems of adaptation, that means: analysis, synthesis, systematization and generalization methods. The author defines the concept of "socialization", "social environment" and "social and educational environment". He emphasizes the peculiarities of interaction of children with special needs and the social environment. The author notes that the integration and socialization of children with special needs is a complex and lengthy process. It requires significant changes in the attitude towards children with disabilities. They require not only pedagogical and psychological support and rehabilitation measures. They need proper conditions for actualization of their abilities, development of personal qualities and needs in social, moral and spiritual selfimprovement. Inclusion of children with special needs in the social environment is to create psychological and pedagogical conditions for learning and communication, the interaction of such a child in an educational institution. The author of the article also notes that full-fledged education of children with special needs can not take place separately from the family. Therefore, the family is a very important and significant component for the socialization of children with special needs. It has the most important and most responsible role in this process. Specialists should help and support such families. The author finds that today the influence of parents of children with special needs on the system of providing educational and rehabilitation services and on making state decisions in this sphere is quite significant. The potential of their capabilities for maximizing integration of children into the social and educational environment needs to be revealed. Provision of specialized care and family support plays a vital role in strengthening social integration and promotes conditions that allow children to adapt to the social environment with the help of inclusive education.
\end{abstract}

Keywords: inclusive education, children with special needs, socialization, social environment, social and educational environment, family, competence. 


\section{ВСТУП}

Постановка проблеми. Нагальною потребою сучасного етапу розвитку демократичної освіти в Україні $€$ створення умов для залучення кожної дитини, людини до навчально-виховного процесу із урахуванням їхніх загальних та спеціальних потреб, особливостей соціального досвіду, рівня розвитку культури, своєрідності ціннісних орієнтацій. Актуальною проблемою освіти XXI століття є залучення дітей з особливими потребами до основного потоку дітей, колективу, спільноти навчального закладу, тобто до інклюзивної освіти. 32012 року і в Україні почала формуватися державна система підтримки таких дітей.

Закордонні та вітчизняні наукові дослідження засвідчують необхідність і важливість організації взаємодії дітей 3 різноманітних культурних середовищ, з відмінними здібностями, своєчасними і особливими потребами, різними ціннісними орієнтаціями в умовах соціального середовища. Організація навчально-виховного процесу учнів різних категорій шляхом удосконалення сприятливих психолого-педагогічних умов, використання корекційнокомпенсаторної складової забезпечує можливості набуття ними соціального досвіду, досвіду міжособистісної взаємодії, саморегулювання моральної поведінки, розвитку власної особистості задля подальшої успішної інтеграції в соціальне середовище [9, с. 172].

Актуальність і необхідність освітньої, соціальної та культурної інтеграції дітей з особливими потребами підкреслюються в роботах вітчизняних науковців А. Колупаєвої, М. Малофєєєва, Н. Назарової, Н. Шматко, М. Чайковського та інших, а також закордонних учених: Ч. Веббер, Т. Лорман, Т. Міттлер, Д. МакГі Річмонд, К. Стафоффорд, Д. Рубейн, С. Хайнес, Д. Харві та інші.

У дослідженнях І. Бгажнової, В. Бондаря, Л. Волкової, І. Гілевич, В. Засенка, О. Мастюкова, Г. Махортової, А. Московкіна, Т. Сак, В. Синьова, Л. Тигранової, Л. Шипіциної особлива увага приділяється питанням надання практичної допомоги особам з особливими потребами в процесі їх інтеграції в суспільство, вивчення спеціальних умов успішної інклюзії, визначення основних напрямів зі включення дітей з особливими потребами до загальноосвітнього процесу.

МЕТА I ЗАВДАННЯ ДОСЛІДЖЕННЯ - визначити можливості для включення дітей з особливими потребами до соціально-освітнього середовища та розкрити проблеми адаптації.

МЕТОДИ ДОСЛІДЖЕННЯ. Методами дослідження виступають аналіз, синтез, систематизація та узагальнення, за допомогою яких таке явище, як включення дітей з особливими потребами в соціально-освітнє середовище, розкладається на складові частини, поєднується на компоненти, упорядковується інформація і робиться висновок щодо можливостей їх включення до соціально-освітнього середовища.

\section{РЕЗУЛЬТАТИ ДОСЛІДЖЕННЯ}

В умовах сучасної системи освіти школи та інші освітні установи набувають все більшої свободи у виборі напрямів, методів і засобів їх розвитку: з'являються нові типи шкіл, упроваджуються інноваційні технології, розробляються і реалізуються авторські програми. Провідні тенденції освіти у світі пов'язані з ідеєю створення умов для всебічного розвитку особистості [2, с. 304].

Важливим аспектом процесу соціалізації особистості є ії власна активність. Процес набуття соціального досвіду або якостей не є процесом механічного перетворення людини в суспільну особистість. Усі зовнішні впливи діють через внутрішні особливості людини (потреби, інтереси, мотиви тощо) та її набутий досвід взаємодії із середовищем. Тому ії ставлення до соціальних цінностей, а також до самих зовнішніх впливів і конкретної ситуації зумовлює відповідну поведінку та вчинки.

Для розуміння розкриємо необхідну термінологію: «соціалізація», «соціальне середовище», «соціально-освітнє середовище». Вони між собою взаємопов'язані.

У наукових дослідженнях $є$ багато визначень терміна «соціалізація». Ми за основу беремо наступне: соціалізація - це набуття людиною соціальних якостей, необхідних для життя в суспільстві та взаємодії із соціальним середовищем (К. Альбуханова-Славська, В. Пазенко).

Соціальне середовище - це сукупність соціальних умов життєдіяльності і розвитку людини (духовних, міжособистісних, виробничих та ін. відносин), що впливають на їі свідомість та поведінку. Структура соціального середовища багаторівнева (мікрорівень - безпосереднє соціальне оточення - сім'я, фрормальна чи неформальна група; мезарівень - регіональні, територіальні, поселенські та інші спільноти, які $є$ носіями і виразниками специфічної культури і способу життя; макрорівень - економічна, соціальна, політична і духовна система відносин). Наявність соціального середовища - необхідна та обов'язкова умова соціалізації особистості.

Також для нашого дослідження $є$ важливим полняття «соціально-освітнє середовище». У психолого-педагогічній науці існує декілька підходів до його визначення як одного із найважливіших чинників розвитку особистості. На думку Н. Гевчук, і ми її поділяємо, соціально-освітнє середовище - це система взаємодії різних соціальних інститутів, які сприяють накопиченню соціального досвіду індивіда, розвитку особистості як структурної одиниці суспільства [2, с. 305-306].

Інтеграція та соціалізація дітей з особливими потребами - це складний процес. Він вимагає суттєвих змін у ставленні до дітей з інвалідністю, які потребують не лише матеріальної, фінансової, гуманітарної підтримки і заходів реабілітації (медичної, професійно-освітньої, соціально-побутової), а й належних умов для отримання знань, актуалізації своїх здібностей, розвитку особистих якостей і потреб. 
Важливою в цьому процесі є соціально-педагогічна реабілітація, яка полягає у створенні таких умов для саморозвитку дитини, в результаті яких виробляється активна життєва позиція особистості. Проте значна частина дітей з особливими потребами, незважаючи на зусилля, що докладаються суспільством 3 метою їх навчання та виховання, ставши дорослими, виявляються непідготовленими до інтеграції у доросле соціальне середовище. Разом з тим, практика свідчать, що будь-яка людина, яка має порушення розвитку, може за відповідних умов стати повноцінною особистістю, розвиватися духовно, забезпечувати себе в матеріальному плані та бути корисною суспільству [7, с. 236-237].

Діти з особливими потребами мають своєрідні особливості розвитку, які не дають їм можливості самостійно, без сторонньої допомоги, входити до соціально-освітнього середовища. Вони виявляються наступним чином:

- неспроможності бути залученим до різноманітних, бажаних видів, фрорм діяльності, що гальмує задоволення всіх особистісних потреб дитини (потреби в самоствердженні, усвідомленні своєї значущості, розвитку), а тому зумовлює усвідомлення відсутності деяких здібностей;

- недостатньому рівні участі у різних видах діяльності, особливо привабливих, що обмежує можливості міжособистісної взаємодії з іншими учнями, розвиток потреби у спілкуванні з ними.

Ці потреби також здатні сприяти розвитку і вдосконаленню інших здібностей таких дітей; неспроможність задовольнити деякі потреби в конкретній діяльності дає можливість компенсувати їх розвиток шляхом досягнення успіхів в інших сферах життя. Тому на соціалізацію дітей з особливими потребами впливають багато чинників та мікрочинників, від яких залежить подальший розвиток дитини [9, с. 173-174].

Значна роль у входженні дитини до соціально-освітнього середовища належить педагогу, його внутрішній позиції, методам та цілям. Саме він обумовлює, яким бути новому поколінню, оскільки «тиражує» не лише зміст свого предмету, а й свій тип мислення, спілкування, поведінки, оцінки подій. Освітні й педагогічні інновації як пошук нового «всередині», як «включення» в дію невикористаного раніше потенціалу учня мають складати духовну складову суб'єкта навчання [4, с. 4-5].

Саме тому головною організаційною формою соціальної адаптації та інтеграції в суспільство дітей з особливими потребами в умовах освітнього середовища є інклюзивна освіта, яка включає осіб з особливими освітніми потребами до соціального середовища [1, с. 32]. Звичайно, протягом десятиліть такі діти були відірвані від суспільства, тому за такий короткий проміжок часу воно ще не готове сприймати їх серед свого оточення. Проте останнім часом за рахунок широкого інформування і розроблення законодавчої та методичної бази в Україні прослідковується тенденція до позитивних змін у ставленні суспільства, загальноосвітніх навчальних закладів, фахівців до дітей 3 особливими потребами та їх батьків [11, с. 344]. Так, польські дослідження свідчать, що відносно того, як ідея інтеграції поширюється, збільшується прийняття людей 3 інвалідністю, включаючи позитивне ставлення до інклюзивної освіти [5, с. 93].

Разом з тим, неправильно вважати, що інклюзивній освіті підлягають всі діти з особливими потребами.

$€$ категорії дітей, які з різних причин не можуть перебувати серед нормотипових дітей, але це не означає, що не відбувається їх соціалізація. Включення їх в соціально-освітнє середовище відбувається в інших типах навчальних закладів: закладах дошкільної освіти компенсуючого типу, спеціальних загальноосвітніх школах, навчальнореабілітаційних центрах, навчально-виховних комплексах та ін. Переваги таких закладів полягають у наявності кваліфікованих фахівців, сприятливих умов для навчання, виховання і корекційно-педагогічної допомоги та великому досвіді роботи з такою категорією дітей. Це якнайкраще сприяє та відкриває широкі можливості для їх соціалізації і входження до соціально-освітнього середовища [1, с. 32].

Від діяльності закладів нового типу значну користь можуть отримувати заклади інклюзивної освіти. Налагоджування зв'язків та тісна співпраця між ними буде сприяти підвищенню фахового рівня педагогічних працівників (на це також спрямована діяльність й Інклюзивно-ресурсних центрів), участі педагогів спеціальних закладів у засіданнях педагогічних рад та методичних об'єднань, отриманню консультацій, залученню вузькопрофільних фахівців до роботи в інклюзивних навчальних закладах тощо.

Проте, важливо розуміти, що соціалізація осіб з особливими освітніми потребами та їх інтеграція до суспільства це не чіткий розклад, план або схема, ніякий навчальний заклад не зможе цього зробити, якщо у цьому процесі не будуть активно задіяні батьки. Тому це кропітка робота батьків і фахівців, їх спільні дії, які сприятимуть розвитку здібностей дитини та її соціально-освітній адаптації й інтеграції [10, с. 166].

Саме сім'я $є$ найкращим середовищем для розвитку особистості дитини, головним інститутом виховання, який відіграє значну роль у розвитку суспільства, особливо якщо ця дитина обмежена у своїх можливостях [10, с. 164]. Разом з тим, сім'я, у якій з'являється дитина з особливими потребами, потрапляє в повністю нову емоційну і суспільну ситуацію, яка порушує її дотеперішнє функціонування. Внаслідок цього у багатьох сім'ях виникають подружні конфлікти, розпадаються сімейні узи, значно обмежуються контакти із зовнішнім оточенням тощо. Така дезорганізація сімейного життя призводить до зміни в емоційних стосунках батьків щодо дитини та застосування невідповідних методів виховання [3, с. 80]. Так не має бути, адже батькам та іншим членам родини належить вирішальна роль у тому, щоб дитина розвивалася, ставала особистістю, яка може приймати самостійні рішення та займати активні життєві позиції. Для цього батьки повинні підвищувати свою компетентність, отримувати спеціальні знання, у відповідь має бути постійний психологічний супровід та підтримка сім'ї, допомога їй в організації освітньої діяльності, відпочинку дитини і т.д. [10, с. 166]. 
Особливу роль в соціалізації відіграє стиль сімейного виховання, загальний психологічний клімат сім'ї, ставлення батьків до дитини. 3 перших днів появи дитини на світ сім'я покликана готувати їі до життя і практичної діяльності, в домашніх умовах забезпечити розумну організацію її життя, допомогти засвоїти позитивний досвід старших поколінь, набути власного досвіду поведінки й діяльності. Саме батьки повинні вчити дитину будувати розумні взаємини 3 однолітками під час прогулянок та спільної діяльності [9, с. 174-175]. Також такі сім'ї вимагають адекватної підтримки з боку спільноти. Адже оточення таких сімей відіграє важливу роль у становленні та розвитку дітей з особливими потребами. Якщо суспільство не готове прийняти цих дітей, то це значно вплине на подальший їх розвиток і соціалізацію [11, с. 335-336].

Проте практика свідчить, що у нас $є$ поширеною низка типових проблем сімей, у яких виховуються діти 3 особливими освітніми потребами. Так, батьки не завжди або невчасно звертаються до Інклюзивно-ресурсних центрів, які є важливим елементом майбутньої соціалізації дитини, відповідно втрачається дорогоцінний час; інколи батьки пропускають найважливішу ланку для соціалізації та соціально-освітньої інтеграції своїх дітей - заклад дошкільної освіти - або ж переводять дітей з молодшої в старшу групу, що шкодить не лише соціалізації, але й розвитку дитини; батьки таких дітей здебільшого самі виконують завдання замість своїх дітей або жорстко нав'язують їм дії й ретельно їх контролюють, що не дозволяє дітям діяти самостійно в різних життєвих ситуаціях і впливає на подальшу соціалізацію, також батьки зазвичай саботують всю «роботу з сім'єю»; ухиляються від «ретельного вивчення проблем сім'ї»; не відвідують заходи, які зазначені в плані роботи закладу; не беруть участь у складанні та корегуванні індивідуального плану розвитку дитини [8, с. 44]. Така ситуація спостерігається тому, що батьки не мають мотивації брати участь у діях, які, на їх думку, ніяк не впливають на те, що насправді їх хвилює. Зміна такого становища можлива лише внаслідок повної зміни акцентів у цьому питанні: фахівці та адміністрація закладу мають вважати батьків «роботодавцями» та «замовниками послуг» усієї системи інклюзивної освіти, а батьки, розуміючи, яка на них лежить значна відповідальність, підвищувати свою компетентність [11, с. 344]. Сучасна практика спеціальної педагогіки та психології свідчить про необхідність активного вивчення всього спектра проблем сім'ї, яка виховує дитину з особливими потребами. Відповідно акцент соціально-педагогічного впливу переноситься на сім'ю особливої дитини, де посилена увага приділяється позитивному впливу близьких на дитину, створенню сприятливих умов для ії навчання, розвитку та соціалізації [6, с. 39].

обговорення. Як бачимо, діти з особливими потребами можуть і мають право навчатися в інклюзивних закладах та бути інтегрованими до соціально-освітнього середовища. Проте і в цьому процесі $є$ певні застереження.

Вже сьогодні ми спостерігаємо картину, коли батьки дітей з особливими освітніми потребами з високим та найвищим рівнем батьківської компетентності хочуть брати участь у прийнятті рішень стосовно роботи навчальних та реабілітаційних закладів, стратегій їх розвитку та реалізації цих стратегій. Відповідно до чинного законодавства вони мають на це право. Разом з тим, батьки мають розуміти, що окрім прав на них лежать обов'язки та велика відповідальність за подальший розвиток своїх дітей.

Науковці та фрахівці часто стверджують, ставлячи у приклад батьків з високою та найвищою батьківською компетентністю, як було б добре, якби усі батьки були такими. Але насправді співпраця з такими батьками не є легкою справою, вона вимагає від самих фахівців постійного професійного зростання, оскільки, щоб взаємодіяти з батьками з найвищою психолого-педагогічною компетентністю, фахівець сам повинен мати найвищу професійну компетентність [11, с. 343-344].

\section{ВИСНОВКИ ТА ПЕРСПЕКТИВИ ПОДАЛЬШИХ ДОСЛІДЖЕНЬ}

Отже, інтеграція дітей з особливими освітніми потребами в соціальне середовище полягає у створенні психологічно-педагогічних умов для навчання та спілкування, взаємодії такої дитини в інклюзивному закладі. Найголовніша роль у цьому процесі належить сім'ї. Надання спеціалізованої допомоги та підтримки такій сім'ї відіграє життєво важливу роль у зміцненні соціально-освітньої інтеграції та сприяє умовам, які дозволяють дітям адаптуватися до соціального середовища.

У майбутніх дослідженнях важливо розглянути проблеми залучення дітей з особливими потребами до спільноти дошкільного навчального закладу, створення в ньому відповідного середовища, орієнтованого на їхній розвиток.

\section{СПИСОК ВИКОРИСТАНИХ ДЖЕРЕЛ}

[1] Гордієнко Н. М. Дослідження соціалізації осіб з особливими потребами в умовах навчально-реабілітаційного центру. На-уковий часопис Національного педагогічного університету імені М.П. Драгоманова. Корекційна педагогіка та спеціальна психологія. 2014. Серія 19. Вип. 25. С. 32.

[2] Гуцуляк Л. І. Соціально-освітнє середовище в педагогічному процесі школи. Молодий вчений. 2017. № 5 (45). С. $304-306$.

[3] Котормус О. А. Інтеграційна освіта у перцепції батьків. Актуальні питання корекційної освіти (педагогічні науки): збірник наукових праць: вип. 9, у 2 т./ за ред. В.М. Синьова, О.В. Гаврилова.- Кам'янець-Подільський: ПП Медобори-2006, 2017. Т.2. С. 80.

[4] Кремень В. Г. Інноваційна людина і сучасна освіта. Вісник Чернігівського національного педагогічного університету імені Т.Г. Шевченка. Серія: Педагогічні науки. 2013. Вип. 110. С. 4-5.

[5] Kulesza E. M. Plusy i minusy edukacji wlaczajacej w opinii kazachskich rodzicow uczniow klas ріеrwszych. Актуальні питання корекційної освіти (педагогічні науки): збірник наукових праць: вип. 9, у 2 т./ за ред. В.М. Синьова, О.В. Гаврилова.- Кам'янецьПодільський: ПП Медобори-2006, 2017. Т.2. С. 93. 
[6] Оксенюк О. Соціальний супровід сім'ї дитини з особливими потребами. Social Work and Education, Vol. 5, No. 1., pp. 39, doi:10.25128/2520-6230.18.1.4

[7] Палилюлько О. М. Шляхи покрашення реабілітації дітей з особливими потребами. Інновації партнерської взаємодії освіти, економіки та соціального захисту в умовах інклюзії та прагматичної реабілітації соціуму: матеріали Міжнародної науковопрактичної конференції, Кам'янець-Подільський, 24-25 квітня 2017 р. Кам'янець-Подільський: Аксіома. 2017. Вип. 2. С. $236-237$.

[8] Сілявіна Ю. Концепт педагогічної реабілітації вихованців з особливими освітніми потребами в сучасному професійно-педагогічному дискурсі. Науковий вісник Мелітопольського державного педагогічного університету. 2016. Вип. 2 (17). С. 44, doi: http://dx.doi.org/10.7905/nvmdpu.v0i17.1599

[9] Соболевська І. Особливості соціалізації розвитку учнів із спеціальними потребами. Вісник Львівського університету. Серія педагогічна. 2004. Вип. 18. С. 172-175.

[10]Сяба М. О. Роль сім'ї у вихованні дітей з особливими потребами. Духовність особистості: методологія, теорія і практика: зб. наук. праць Східноукраїнського національного університету імені Володимира Даля / гол. ред. Г.П. Шевченко. Лу-ганськ: вид-во СНУ ім. В. Даля. 2013. Вип. 3 (56). С. 164, 166

[11] Хворова Г. М. Зміст та рівні батьківської компетентності у корекційно-педагогічному аспекті. Актуальні питання корекцій-ної освіти (педагогічні науки). Кам'янець-Подільський: Медобори-2006. 2015. Вип. 5. Том 2. С. 335-336, 341-345.

\section{REFERENCES (TRANSLATED AND TRANSLITERATED)}

[1] Gordienko N. M. (2014). Doslidzhennja socializaciji osib z osoblyvymy potrebamy v umovakh navchaljno-reabilitacijnogho centru (Research of socialization of persons with special needs in the conditions of a training and rehabilitation center). Naukovyi chasopys Natsionalnoho pedahohichnoho universytetu imeni M.P. Drahomanova. Korektsiina pedahohika ta spetsialna psykholohiia, 19/25. S. 32. (in Ukrainian)

[2] Ghuculjak L. I. (2017). Socialjno-osvitnje seredovyshhe v pedaghoghichnomu procesi shkoly (Socio-educational environment in the pedagogical process of school). Molodyj vchenyj. № 5 (45). S. 304-306. (in Ukrainian)

[3] Kremen V. G. (2013). Innovacijna ljudyna i suchasna osvita (Innovative person and modern education). Visnyk Chernihivskoho natsionalnoho pedahohichnoho universytetu imeni T.H. Shevchenka. Seriia: Pedahohichni nauky, 110, 4-5. (in Ukrainian)

[4] Kotormus O. A. (2017). Integhracijna osvita u percepciji batjkiv (Integration education in parental perception). Aktualjni pytannja korekcijnoji osvity (pedaghoghichni nauky): zbirnyk naukovykh pracj: vyp. 9, u 2 t./ za red. V.M. Synjova, O.V. Ghavrylova.-Kam'janecjPodiljsjkyj. T.2. C. 80. (in Ukrainian)

[5] Kulesza E. M. (2017). Plusy i minusy edukacji wlaczajacej w opinii kazachskich rodzicow uczniow klas pierwszych (Pros and cons of education including in the opinion of Kazakh parents of first graders). Aktualjni pytannja korekcijnoji osvity (pedaghoghichni nauky): zbirnyk naukovykh pracj: vyp. 9, u 2 t./ za red. V.M. Synjova, O.V. Ghavrylova. Kam'janecj-Podiljsjkyj. T.2. S. 93. (in Polish)

[6] Oksenjuk O. (2018). Socialjnyj suprovid sim'ji dytyny z osoblyvymy potrebamy (Social support for the family of a child with special needs). Social Work and Education, Vol. 5, No. 1., pp. 39. (in Ukrainian)

[7] Palilulko O. M. (2017). Shljakhy pokrashennja reabilitaciji ditej z osoblyvymy potrebamy (Ways to Improve the Rehabilitation of Children with Special Needs). Innovatsii partnerskoi vzaiemodii osvity, ekonomiky ta sotsialnoho zakhystu v umovakh inkliuzii ta prahmatychnoi reabilitatsii sotsiumu: materialy Mizhn. nauk.-prakt. konf., 2, 236-237. (in Ukrainian)

[8] Silyavina Y. (2016). Koncept pedaghoghichnoji reabilitaciji vykhovanciv z osoblyvymy osvitnimy potrebamy v suchasnomu profesijnopedaghoghichnomu dyskursi (Concept of pedagogical rehabilitation of pupils with special educational needs in modern vocational and pedagogical discourse). Naukovyy visnyk Melitopol's'koho derzhavnoho pedahohichnoho universytetu, 2 (17). S. 44. doi: http://dx.doi.org/10.7905/nvmdpu.v0i17.1599 (in Ukrainian)

[9] Sobolevskaya I. (2004). Osoblyvosti socializaciji rozvytku uchniv iz specialjnymy potrebamy (Features of socialization of pupils with special needs development). Visnyk Lvivskoho universytetu. Seriia pedahohichna, 18, 172-175. (in Ukrainian)

[10] Syaba M. O. (2013). Rolj sim'ji u vykhovanni ditej z osoblyvymy potrebamy (The role of the family in the education of children with special needs). Dukhovnist osobystosti: metodolohiia, teoriia i praktyka: zb. nauk. prats Skhidnoukrainskoho natsionalnoho universytetu imeni Volodymyra Dalia, 3 (56). S. 164, 166. (in Ukrainian)

[11] Hvorova G. M. (2015). Zmist ta rivni batjkivsjkoji kompetentnosti u korekcijno-pedaghoghichnomu aspekti (The content and level of parental competence in the correctional-pedagogical aspect). Aktualni pytannia korektsiinoi osvity (pedahohichni nauky): zb. nauk. prats Kamianets-Podilskoho natsionalnoho universytetu imeni Ivana Ohiienka, 5/2, 335-336, 341-345. (in Ukrainian) 